\title{
Brannskadede innlagt i norske sykehus - en populasjonsbasert studie
}

\begin{abstract}
BAKGRUNN Hensikten med denne artikkelen er å belyse omfanget av brannskader i Norge, bedømt ut fra de pasienter som i et kalenderår hadde en brannskade som førte til sykehusinnleggelse.
\end{abstract}

MATERIALE OG METODE Artikkelen bygger på data innhentet fra Norsk pasientregister for pasienter utskrevet fra norske sykehus i 2012 med brannskade som hoveddiagnose, supplert med aktivitetsdata for barn innlagt ved Brannskadeavsnittet, Haukeland universitetssykehus, i perioden 2013-15.

RESULTATER I 2012 var 620 personer (12,4/100 000 innbyggere) innlagt i sykehus med brannskade. 393 pasienter $(63,4 \%)$ var menn. 375 pasienter $(60 \%)$ hadde mer enn ett sykehusopphold, og 124 (20\%) hadde opphold ved mer enn ett sykehus. 367 pasienter (59\%) hadde en liggetid på under åtte døgn. For hele gruppen var gjennomsnittlig liggetid 11,3 døgn (SD 18,8 døgn). Mange av de brannskadede var unge, gjennomsnittsalderen var 27,4 år (SD 26,0 år). Hele 183 pasienter (30 \%) var under tre år. Barn i denne aldersgruppen var innlagt 12 ganger hyppigere for brannskade enn barn $\geq 5$ år og voksne.

FORTOLKNING Vi fant ingen sikker reduksjon i brannskade som årsak til innleggelse i norske sykehus i 2012 sammenlignet med resultater fra tidligere studier for perioden 1992-2007. Det bør være et stort potensial for mer effektiv forebygging av brannskade i aldersgruppen < 3 år, der skålding (78\%) og kontakt med varme overflater loftest ovner) (17\%) er dominerende skademekanismer.

Brannskader behandlet ved norske sykehus har vært omtalt i Tidsskriftet, siste gang var omtalen basert på data for året 1998 (1). Siden 2009 har det til datafilene i Norsk pasientregister (NPR) vært knyttet et pasientspesifikt løpenummer som et pseudonym for fødselsnummeret. Det samme løpenummeret brukes på tvers av alle årganger og sektorer der det innrapporteres data til registeret. Løpenummeret gjør det mulig å belyse pasienter med reinnleggelser for samme sykdom og å følge pasienter som er flyttet mellom sykehus. Vi har i denne artikkelen ønsket å få frem informasjon om pasientene som i et kalenderår (2012) hadde hatt en så alvorlig brannskade at de ble innlagt i sykehus i Norge.

Mange små og mindre brannskader behandles poliklinisk. I denne studien har vi lagt mest vekt på pasientene med mer omfattende brannskader, definert ved at de hadde vært innlagt i sykehus i minst ett døgn for brannskade (eller der brannskaden var så alvorlig at pasienten døde innleggelsesdøgnet).

\section{Materiale og metode}

I Norsk pasientregister ble det i september 2013 utført et uttrekk blant opphold ved alle norske sykehus med akuttfunksjon. Uttrekket omfattet alle pasienter utskrevet i perioden 1. januar-31. desember 2012 med brannskade (ICD-10 (2): T20-T25, T29, eller T30, alle med tredje siffer .0-.3, eller T31.0T31.9) som hoveddiagnose. Inkludert ble også pasienter med røykskade (T58, eller T59.7-T59.9) som hoveddiagnose og brannskade som bidiagnose.

Dette råmaterialet ble så bearbeidet videre før utlevering fra Norsk pasientregister slik at man ikke tok med pasienter som var registrert kun med sykehusopphold for brannskade med liggetid 0 døgn (fig 1). Det gjensto da 620 unike pasienter (med til sammen 1976 opphold) som ble analysert videre.

Anonymiserte data ble fra Norsk pasientregister utlevert i tabellform. For enkeltindivider omfattet informasjonen kun fødselsår, kjønn, antall opphold med brannskade som hoveddiagnose og samlet liggetid. For aldersgrupper med få pasienter ble alder oppgitt som et intervall (f.eks. 78-82 år), for disse pasientene er alder beregnet som middelverdien i oppgitt aldersintervall (i eksemplet 80 år).

Liggetid for enkeltopphold er regnet som utskrivningsdato minus innleggelsesdato. For pasienter med flere opphold er samlet liggetid beregnet som sum av varigheten av to eller flere opphold.

Alder er regnet som 2012 minus fødselsår, siden det av personvernhensyn ikke ble gitt tilgang til fødselsdatoer. Dette gir en viss systematisk unøyaktighet, slik at forekomsten av brannskade i den laveste aldersgruppen ( $<3$ år) kan være estimert noe lavt.

På institusjonsnivå ble det utlevert informasjon om samlet antall pasienter, antall opphold og samlet antall liggedøgn.

\author{
Henning Onarheim \\ henning.onarheim@helse-bergen.no \\ Kirurgisk serviceklinikk \\ Haukeland universitetssykehus \\ og \\ Klinisk institutt 1 \\ Universitetet i Bergen \\ Ragnvald Ljones Brekke \\ Avdeling for plastikkirurgi og brannskade \\ Kirurgisk klinikk \\ Haukeland universitetssykehus \\ Anne Berit Guttormsen \\ Kirurgisk serviceklinikk \\ Haukeland universitetssykehus \\ og \\ Klinisk institutt 1 \\ Universitetet i Bergen
}

ㄴ. Engelsk oversettelse på www.tidsskriftet.no

\section{HOVEDBUDSKAP}

Årlig blir over 620 pasienter innlagt ved norske sykehus etter brannskade

Forebyggende tiltak mot brannskade bør rettes spesielt mot barn under tre år. Disse er spesielt utsatt, særlig for skåldingsskader, og ble i 2012 innlagt med brannskade 12 ganger hyppigere enn barn $\geq 5$ år og voksne

Til tross for vekt på skadeforebyggende tiltak ser vi over en 20 -årsperiode ingen sikker reduksjon i antall brannskadetilfeller i norske sykehus 
1491 enkeltpasienter, alle med ett opphold med liggetid 0 døgn

$=1491$ poliklinisk behandlede pasienter

663 enkeltpasienter med to eller flere opphold, alle med liggetid 0 døgn, til sammen 2271 opphold

$=663$ poliklinisk behandlede pasienter

Figur 1 Uttrekk av studiegruppe: opphold i sykehus med brannskade i 2012 (fra Norsk pasientregister)

For å belyse årsaker til brannskader hos småbarn er det i tillegg fra et lokalt kvalitetsregister ved Brannskadeavsnittet, Haukeland universitetssykehus, for alle barn $<3$ år innlagt $i$ årene 2013-15 hentet informasjon om skadetype, omstendigheter, skadet areal, liggetid og antall operative inngrep.

Insidens er beregnet $\mathrm{i}$ forhold til befolkningstall og kjønn i ulike aldersgrupper $\mathrm{i}$ Norge per 1. januar 2012 (totalt 4985870 innbyggere) (3).

\section{Statistikk}

Der ikke annet er oppgitt, er resultater presentert som middelverdi og standardavvik. Insidens av brannskade hos menn og kvin- ner i ulike aldergrupper er sammenlignet med khikvadrattest (PRISM 5.0, GraphPad Software, La Jolla, CA, USA).

\section{Godkjenninger}

Helsedirektoratet ved avdeling Norsk pasientregister har godkjent søknad og utlevert statistikk og anonyme opplysninger. Studien er godkjent av regional etisk komité avdeling vest (2013/538).

\section{Resultater}

Uttrekket fra Norsk pasientregister omfattet 620 enkeltpasienter med brannskade (fig 1). Dette tilsvarer 12,4 pasienter innlagt med brannskade per 100000 innbyggere og år.

Tabell 1 Brannskadede i Norge i 2012: aldersfordeling, antall pasienter og liggetider (for pasienter med flere opphold for brannskade er varigheten beregnet som sum av alle enkeltopphold) ${ }^{1}$

\begin{tabular}{|c|c|c|c|c|c|}
\hline \multirow[b]{2}{*}{ Alder (år) } & \multicolumn{2}{|c|}{ Antall pasienter } & \multicolumn{3}{|c|}{ Liggetid (døgn)1 } \\
\hline & Menn & Kvinner & Samlet & Gjennomsnitt (SD) & Median \\
\hline$<3$ & 116 & 67 & 1964 & $10,7(13,1)$ & 6 \\
\hline $3-4$ & 13 & 20 & 277 & $8,4(7,9)$ & 7 \\
\hline $5-9$ & 13 & 19 & 152 & $4,8(5,3)$ & 2 \\
\hline $10-19$ & 26 & 11 & 285 & $7,7(10,7)$ & 1 \\
\hline $20-39$ & 92 & 33 & 1175 & $9,4(24,5)$ & 2 \\
\hline $40-59$ & 89 & 35 & 1448 & $11,7(19,3)$ & 4 \\
\hline $60-79$ & 36 & 28 & 1362 & $21,8(27,2)$ & 10,5 \\
\hline$\geq 80$ & 8 & 14 & 318 & $14,3(12,3)$ & 14 \\
\hline Sum & 393 & 227 & 6981 & $11,3(18,8)$ & 5 \\
\hline
\end{tabular}

393 pasienter $(63,4 \%)$ var menn. Figur 2 viser antall brannskadede per 100000 innbyggere i ulike aldersgrupper og fordelt på kjønn. Der var en signifikant overvekt av brannskade hos menn, både blant småbarn og $\mathrm{i}$ aldersgruppene $10-59$ år.

Mer enn en tredel av de brannskadede var barn, og hele 216 pasienter $(34,8 \%)$ var under fem år. Den store andelen små barn medvirket til at gjennomsnittsalderen for pasienter innlagt med brannskade var lav: 27,4 år (SD 26,0 år), med en median alder på 22,5 år.

Det samlede antall liggedøgn $(n=6981)$ tilsvarer at i gjennomsnitt er 20 norske sykehussenger hvert døgn belagt av pasienter med brannskade. Liggetiden var svært skjevfordelt i retning relativt korte liggetider (gjennomsnittlig liggetid var 11,3 døgn (SD 18,8 døgn), median liggetid fem døgn) (tab 1). For 367 pasienter (59,2\%) var liggetiden på under åtte dager. Det andre ytterpunktet var de 15 pasientene med liggetid $>8$ uker, samlet 1438 liggedøgn, noe som utgjorde $20,6 \%$ av alle liggedøgn på grunn av brannskade.

For de 620 pasientene var det i alt registrert 1976 opphold. 375 pasienter $(60 \%)$ hadde mer enn ett opphold. Flere opphold hos samme pasient reflekterer trolig at mange brannskadede planlagt kommer tilbake for ett (eller flere) bandasjeskift/sårstell, at enkelte reinnlegges med fortsatte sårproblemer, og også at brannskadepasienter flyttes mellom sykehus. Hver femte pasient hadde opphold for brannskade ved mer enn ett sykehus. Av disse hadde 109 pasienter $(17,6 \%)$ opphold ved to sykehus og 15 pasienter $(3,4 \%)$ opphold ved tre eller flere sykehus).

I tillegg til de 620 pasientene som hadde vært innlagt i sykehus med brannskade, hadde ytterligere 2154 pasienter hatt sykehuskontakt på grunn av brannskade, men uten innleggelse (fig 1).

Haukeland universitetssykehus har landsfunksjon for avansert brannskadebehandling. 103 av 620 pasienter $(16,7 \%)$ var i 2012 behandlet ved dette sykehuset, med i alt 2148 liggedøgn for brannskade (30,7\% av alle liggedøgn).

Syv pasienter, tre menn og fire kvinner, var registrert som døde ved utskrivning. Seks av dem hadde liggetider på mellom ett døgn og tre uker, mens den siste døde etter et lengre opphold i sykehus. Av dem som døde av brannskade, var det en pasient under 15 år og fire som var 70 år eller eldre.

183 av pasientene $(29,5 \%)$ var under tre år. I denne aldersgruppen var således brannskade 12 ganger hyppigere enn for voksne og for barn over fem års alder (fig 2).

Ved Brannskadeavsnittet ved Haukeland universitetssykehus var det i årene 2013-15 innlagt 344 pasienter med brannskade. 114 
av pasientene $(33 \%)$ var barn $<3$ år. Av disse hadde hele 89 (78\%) skåldingsskader og 19 (17\%) brannskader etter kontakt med varme overflater (tab 2).

\section{Diskusjon}

Vår gjennomgang av brannskadede innlagt ved alle norske sykehus i 2012 viser at denne type skade fortsatt er en vesentlig årsak til innleggelse. Mest alarmerende er den mer enn 12 ganger hyppigere årsaken til innleggelse av barn under tre år sammenlignet med barn $\geq 5$ år og voksne. Mange brannskader hos småbarn kan unngås ved større oppmerksomhet omkring farlige situasjoner, særlig i hjemmet: varme væsker, usikrede varmtvannsarmaturer og varme overflater (peisovner).

Uthenting av data fra Norsk pasientregister gir mulighet for å sammenstille informasjon knyttet til pasienter med flere opphold (reinnleggelser) eller flere opphold ved forskjellige sykehus for samme skade.

Denne undersøkelsen har metodiske begrensninger: På individnivå hadde vi kun tilgang til opplysninger om fødselsår, kjønn, antall innleggelser og samlet antall liggedøgn. Tilgang til mer detaljert informasjon på individnivå, spesielt om diagnoser og koding for ytre årsak til skade, kunne gitt andre analysemuligheter, uten at konfidensialiteten reelt sett burde være truet.

En styrke ved undersøkelsen er likevel at datagrunnlaget bør være nær komplett. Antallet pasienter identifisert som brannskadet vil likevel være minimumstall. For å finne pasienter med akutt brannskade, uten å få med pasienter med brannskade som en (mer eller mindre tilfeldig) bidiagnose, ble søket gjort etter pasienter med brannskade som hoveddiagnose (eller med røykskade som hoveddiagnose og brannskade som bidiagnose). Dermed kan vi potensielt ikke ha fanget opp enkelte brannskadede, for eksempel dersom A41.0 (stafylokokksepsis, som er en reell komplikasjon) var angitt som hoveddiagnose og brannskaden som bidiagnose. Liggetidene kan også være svakt underestimert, ved at vi ikke fikk med alle opphold for de relativt få pasienter som hadde flere opphold fordelt på begge sider av et årsskifte.

Det samlede omfang av brannskadebehandling kan også være noe underestimert, ettersom vi potensielt ikke fanget opp pasienter som ble reinnlagt med andre komplikasjoner i forløpet etter en brannskade. Uttrekket omfattet heller ikke opphold for videre rehabilitering etter brannskade, og vi har heller ikke satt søkelys på dem som hadde opphold for rekonstruktive inngrep i forløpet etter skaden.

I tillegg til våre 620 pasienter hadde ytterligere 2154 kontaktet sykehus på grunn av brannskade, men uten at de ble innlagt (fig 1).

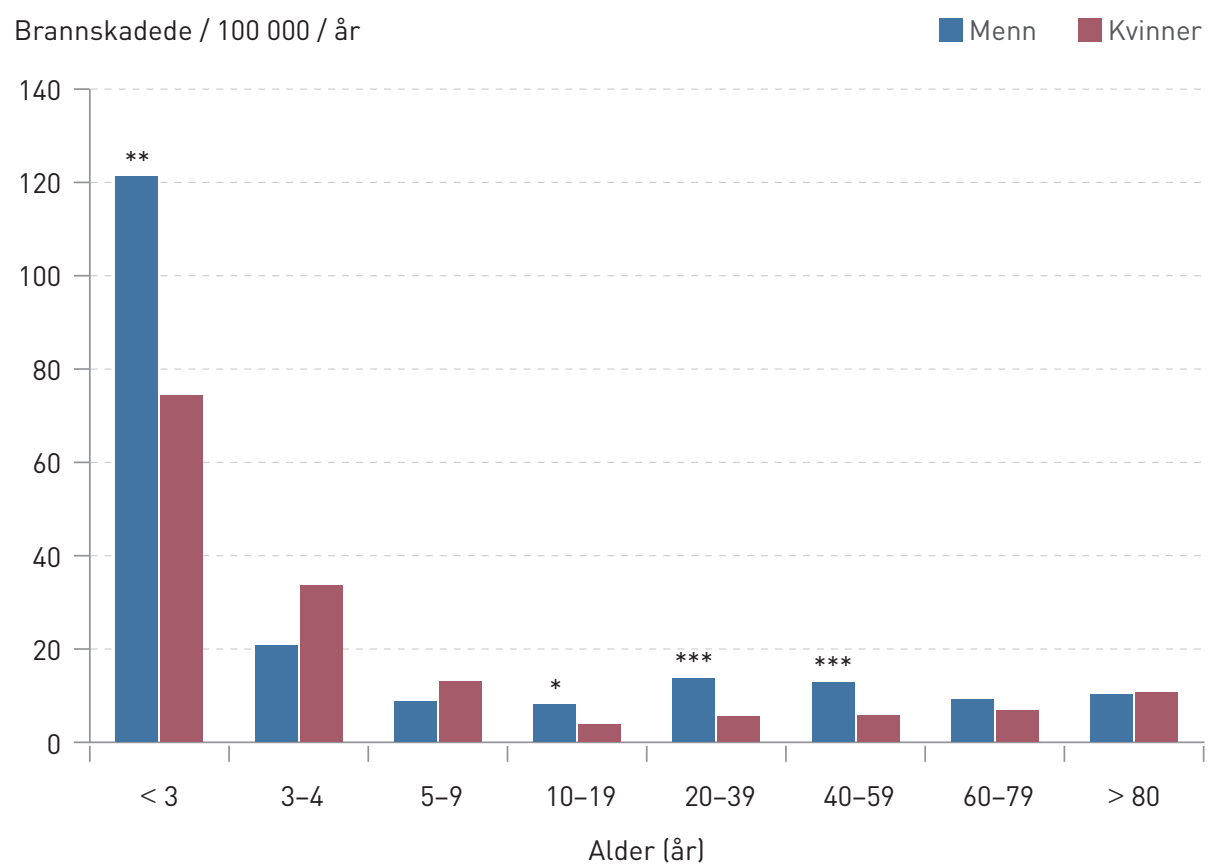

Figur 2 Aldersjustert insidens av brannskadede innlagt i sykehus i Norge i 2012. Grunnlagsdata er hentet fra Norsk pasientregister. Antall innbyggere i ulike aldersgrupper er hentet fra Statistisk sentralbyrå (3). ${ }^{*} p<0,05$, ${ }^{* *} p<0,005,{ }^{* * *} p<0,0001$ for forskjell mellom kjønn
Årlig er altså i underkant av 3000 personer med brannskade i kontakt med norske sykehus. I tillegg kommer et betydelig antall mindre brannskader som blir behandlet ved legekontorer og lokale legevakter.

De brannskadede representerer en svært heterogen pasientgruppe når det gjelder utstrekning av skadet hudområde og skadedybde. Erfaring fra en tidligere norsk undersøkelse viste at koding for brannskadet hudareal (ICD-10; T31.0-T31.9) var angitt så sjelden (kun hos $23 \%$ ) (4) at dette ikke ga tilstrekkelig grunnlag for analyse av skadeutbredelse. I dette materialet var det heller ikke tilgjengelig koder for ytre årsaker til sykdommer, skader og dødsfall (V0n-Y98), noe som kanskje kunne ha bidratt med informasjon omkring skadeårsaker.

I årene 1999-2010 døde det i Norge årlig i gjennomsnitt 58 personer ved brann (3). Langt de fleste av dem som omkommer, dør som var innlagt i sykehus med brannskade $\mathrm{i}$ 2012 døde $(1,1 \%)$. Dette er en lavere andel døde enn det man fant $\mathrm{i}$ to tidligere norske undersøkelser $(1,4)$, men på linje med et engelsk nasjonalt brannskademateriale for 2010, som for brannskadede viste en 30dagersmortalitet på $0,9 \%$ (5).

I europeiske materialer er det svært stor spredning i oppgitt forekomst av brannskade: fra to til 29 innlagte brannskadede/ 100000 innbyggere/år (6). For Norge er det her funnet en forekomst av brannskadede innlagt i sykehus på 12,4/100 000 innbyggere/år. Våre tall passer med tall fra Sverige (året 2004): 13,1 brannskadede pasienter/ 100000 innbyggere/år (7) og et nederlandsk materiale fra 2011 med 8,5 brannskadede pasienter/100 000 innbyggere/år (8). Brewster og medarbeidere (5) oppga derimot i et engelsk materiale 24 brannskadede pasien- på brannstedet. Syv av de 620 pasientene

Tabell 2 Skadeårsaker for barn < 3 år. Basert på barn innlagt ved Brannskadeavsnittet, Haukeland universitetssykehus, i perioden 2013-15

\begin{tabular}{lccc} 
Skadetype & Antall barn & $\begin{array}{c}\text { Liggetid } \\
\text { [døgn) }\end{array}$ & $\begin{array}{c}\text { Antall } \\
\text { operasjoner }\end{array}$ \\
Skålding & 89 & 1315 & 39 \\
Kontakt & 19 & 248 & 7 \\
$\begin{array}{l}\text { Andre årsaker lantenning av hår, kjemisk, } \\
\text { elektrisk, friksjon) }\end{array}$ & 6 & 85 & 9 \\
Sum & 114 & 1648 & 55 \\
\hline
\end{tabular}


Tabell 3 Sykehusinnleggelser for brannskade i Norge over en 35-årsperiode. I tallene for 1977, 1992 og 1999 var det ikke korrigert for reinnleggelser og flyttinger mellom sykehus'

\begin{tabular}{lcccc}
\hline År & $\begin{array}{c}\text { Pasienter innlagt } \\
\text { for brannskade }\end{array}$ & $\begin{array}{c}\text { Befolkning per 1. januar } \\
\text { i året (3) }\end{array}$ & Pasienter/100 000/år & Førsteforfatter (referanse) \\
1977 & $793^{1}$ & 4035202 & $19,7^{1}$ & NOU 1979: 41 (10) \\
1992 & 7091 & 4273634 & $16,6^{1}$ & Onarheim (9) \\
1999 & $701^{1}$ & 4445329 & 15,91 & Onarheim (1) \\
2007 & 726 & 4681134 & 15,5 & Onarheim (4) \\
2012 & 620 & 4985870 & 12,4 & Dette materialet \\
\hline
\end{tabular}

ter/100 000 innbyggere/år, men dette siste tallet var ikke korrigert for reinnleggelser.

$30 \%$ av alle liggedøgn på grunn av brannskade i 2012 var knyttet til opphold ved Haukeland universitetssykehus. I perioden $2008-$ 15 så vi ved Brannskadeavsnittet en aktivitetsøkning - det var $60 \%$ flere henviste pasienter og $60 \%$ flere liggedøgn (Onarheim, upubliserte data). Selv om ikke det samlede antall brannskadede eller omfanget av brannskade nødvendigvis øker, synes nå en noe større andel av pasientene å bli henvist videre til spesialavdeling. En lignende tendens er for perioden 1995-2010 sett i Nederland: $60 \%$ økning i antall pasienter behandlet ved de tre nederlandske brannskadesentrene, mens antall brannskader i landet var konstant (8).

Sammenstillingen av våre forekomstdata med tall fra fire tidligere norske undersøkelser foretatt over en 35-årsperiode $(1,4,9$, 10) viste riktignok at antallet brannskader $i$ 2012 var $35 \%$ lavere enn i det eldste materialet med tall fra 1977 (10) (tab 3). Grunnet forskjeller i fremgangsmåte for å trekke ut data og ulik mulighet for å kunne korrigere for reinnleggelser og flytting mellom avdelinger kan vi neppe fastslå at man i 2012 har lyktes med å redusere insidensen av brannskade, bedømt ut fra antall brannskadede innlagt i sykehus i Norge sammenlignet med situasjonen 20 år tidligere (9).
Godtgjørelse til Norsk pasientregister for uttrekk av rådata og primær bearbeiding av data ble dekket av forskningsmidler opprinnelig gitt av Norsk Hydro.

Vi har benyttet data fra Norsk pasientregister (NPR). Forfatterne er eneansvarlige for tolkning og presentasjon av de utleverte data. Registeret har ikke ansvar for analyser eller tolkninger basert på utleverte data.

\section{Henning Onarheim (f. 1954)}

er dr.med., spesialist i anestesiologi, overlege og professor II.

Forfatter har fylt ut ICMJE-skjemaet og oppgir ingen interessekonflikter.

\section{Ragnvald Ljones Brekke (f. 1977)}

er spesialist i plastikkirurgi og avdelingsoverlege.

Forfatter har fylt ut ICMJE-skjemaet og oppgir ingen interessekonflikter.

\section{Anne Berit Guttormsen (f. 1958)}

er dr.philos., spesialist i anestesiologi, overlege og professor.

Forfatter har fylt ut ICMJE-skjemaet og oppgir ingen interessekonflikter.

\section{Litteratur}

1. Onarheim H, Vindenes HA. Sykehusopphold for brannskade. Tidsskr Nor Lægeforen 2004; 124 2130-2.

2. ICD-10. Den internasjonale statistiske klassifikasjonen av sykdommer og beslektede helseproblemer. Oslo: Sosial- og helsedirektoratet, 2005.

3. Statistisk årbok 2013. Oslo: Statistisk sentralbyrå, 2013

4. Onarheim H, Jensen SA, Rosenberg BE et al. The epidemiology of patients with burn injuries admitted to Norwegian hospitals in 2007. Burns 2009 35: $1142-6$

5. Brewster CT, Coyle B, Varma S. Trends in hospital admissions for burns in England, 1991-2010: a descriptive population-based study. Burns 2013, 39: 1526-34

6. Brusselaers N, Monstrey S, Vogelaers D et al. Severe burn injury in Europe: a systematic review of the incidence, etiology, morbidity, and mortality. Crit Care 2010; 14: R188.

7. Åkerlund E, Huss FRM, Sjöberg F. Burns in Sweden: an analysis of 24,538 cases during the period 1987-2004. Burns 2007; 33: 31-6.

8. Dokter J, Vloemans AF, Beerthuizen GI et al. Epidemiology and trends in severe burns in the Netherlands. Burns 2014; 40: 1406-14.

9. Onarheim H, Røttingen JT. Brannskadede innlagt i sykehus i 1992. Færre skadetilfeller og kortere liggetid også i Norge? Tidsskr Nor Lægeforen 1994; 114: 2244-6.

10. Norges offentlige utredninger. Brannskadebehandling og -beredskap i Norge. NOU 1979: 41. Oslo: Universitetsforlaget, 1979.

Mottatt 27.1.2016, første revisjon innsendt 10.5. 2016, godkjent 13.9. 2016. Redaktør: Geir W. Jacobsen. 